\title{
PENDAFTARAN TANAH SISTEMATIS LENGKAP (PTSL) TERHADAP TANAH TONGKONAN
}

\author{
Oleh: \\ Joshua Melvin Arung La'bi' ${ }^{1}$, Sri Susyanti Nur ${ }^{2}$, dan Kahar Lahae ${ }^{3}$ \\ 1,2, ${ }^{3}$ Universitas Hasanuddin \\ 1.jomel1801@gmail.com; ${ }^{2}$ srisusyanti23@gmail.com; ${ }^{3}$ klahaefhuh84@yahoo.co.id
}

\begin{abstract}
ABSTRAK: Tanah Tongkonan merupakan salah satu bentuk tanah milik masyarakat hukum adat yang ikut serta kedalam program Pendaftaran Tanah Sistematis Lengkap (PTSL), yang dilakukan oleh Badan Pertanahan Nasional Kabupaten Toraja Utara berdasarkan Peraturan Menteri Agraria dan Tata Ruang/Kepala Badan Pertanahan Nasional Nomor 6 Tahun 2018 tentang Pendaftaran Tanah Sitematis Lengkap (PTSL), yang mana hal tersebut bertentangan Peraturan Pemerintah Nomor 24 Tahun 1997 Tentang Pendaftaran Tanah. Penelitian ini bertujuan untuk menganalisis bentuk Pendaftaran Tanah Sistematis Lengkap (PTSL) terhadap tanah tongkonan. Penelitian ini menggunakan metode penelitian empiris, dengan menganalisis data yang terkumpul melalui wawancara dan studi kepustakaan. Hasil penelitian ini menunjukkan bahwa apabila tanah tongkonan didaftarkan melalui program pendaftaran tanah sistematis lengkap (PTSL) akan menimbulkan berbagai permasalahan terutama yang berwenang sebagai pemegang sertifikat hak atas tanah tongkonan, dan kemudian pemberian hak melalui penerbitan sertifikat bertentangan dengan semangat Undang-Undang Nomor 5 Tahun 1960 tentang Peraturan Dasar Pokok Agraria (UUPA).
\end{abstract}

KATA KUNCI: Tanah Tongkonan, Pendaftaran Tanah Sistematis Lengkap (PTSL), Badan Pertanahan Nasional (BPN)

ABSTRACT: Tongkonan land is a form of land belonging to customary law communities that participates in the complete systematic land registration program, which is carried out by the North Toraja Regency National Land Agency, which contradicts Government Regulation Number 24 of 1997 concerning Land Registration. This study aims to analyze the form of Complete Systematic Land Registration of tongkonan land. This study uses empirical research methods, by analyzing data collected through interviews and literature study. The results of this study indicate that if the tongkonan land is registered through the complete systematic land registration program, it will cause various problems, especially those who are authorized as holders of tongkonan land titles, and then granting rights through the issuance of certificates is contrary to the spirit of Law Number 51960 concerning Basic Agrarian Regulations.

KEYWORDS: Tongkonan Land, Complete Systematic Land Registration, National Land Agency

\section{PENDAHULUAN}

Bidang-bidang tanah yang dimasa Hindia Belanda tidak terdaftar secara rectcadaster dan umumnya digolongkan sebagai tanah adat dan merupakan sasaran pendaftaran yang utama. Selain itu, kemudahan terhadap mayoritas anggota masyarakat yang tidak memiliki alat bukti tertulis pun dibantu dengan cara pembuktian melalui penguasaan fisik secara nyata maksudnya bidang tanah 
yang secara terus-menerus telah dikuasai selama 20 (dua puluh) tahun baik oleh pihak yang sedang menguasai ataupun pendahulunya, dapat didaftar dan diterbitkan sertifikatnya. (Cris Lunnay dan Herman Soesangobeng, 1998)

Istilah "menguasai" atau "dikuasai dengan dimiliki" ataupun "kepunyaan dalam konteks yuridis" mempunyai arti atau makna yang berbeda dan menimbulkan akibat hukum yang berbeda pula. Arti "dikuasai" tidak sama dengan pengertian "dimiliki". Jika menyebutkan tanah tersebut dikuasai atau menguasai dalam arti "possesion", maka makna yuridisnya adalah tanah tersebut dikuasai seseorang secara fisik yang dalam arti faktual digarap, dihuni, namun belum tentu bahwa secara yuridis dia adalah pemilik atau yang mempunyai tanah tersebut, pada umumnya hanya mampu dibuktikkan hak atas tanahnya, dengan bukti nyata bahwa ia menduduki atau menguasai secara fisik tanahnya tersebut. (Farida Patittingi, 2011) Demikian juga bila menyebutkan bahwa tanah tersebut di miliki atau kepunyaan dalam arti "Ownership" memilik pengertian dalam yuridis bahwa tanah tersebut merupakan tanah milik atau kepunyaan, namun bukan berarti pula secara fisik menguasai tanah tersebut karena mungkin adanya hubungan kerjasama atau kontraktual tertentu. (Maria Farida Naibaho, 2015)

Hak atas tanah adat yang tunduk kepada hukum adat telah diadakan ketentuan khusus, yaitu dengan Surat Keputusan Menteri Dalam Negeri Nomor 26 DDA/1970, dimana konversi dari hakhak adat tidak ada batas konversi karena pertimbangan khusus mengenai biaya, prosedur, dan ketidakpedulian dari rakyat untuk mensertifikatkan tanahnya. (Muhammad Ilham Saputra dan Sri Wildan Ainun Mardiah, 2019) UndangUndang Nomor 5 Tahun 1960 tentang Peraturan Dasar Pokok-Pokok Agraria
(UUPA) beserta Peraturan Pemerintah Nomor 24 Tahun 1997 tentang Pendaftaran Tanah, tidak memerintahkan pendaftaran hak ulayat dan juga tidak dimasukkan ke dalam golongan objek pendaftaran tanah. Akan tetapi melalui Pasal 3 UUPA mengakui keberadaan tanah ulayat, sementara itu menurut Pasal 1 Ayat 2 Peraturan Menteri Agraria Dan Tata Ruang/Kepala BPN Nomor 18 Tahun 2019 tentang Tata Cara Penatausahaan Tanah Ulayat Kesatuan Masyarakat Hukum Adat, yang dimana menjelaskan bahwa hubungan masyarakat hukum adat dengan tanah ulayat merupakan hubungan menguasai, bukan hubungan milik yang kemudian menjadikan tanah ulayat itu tidak termasuk kedalam obyek pendaftaran..

Tanah tongkonan adalah salah satu bentuk tanah adat, dalam pengertian luas istilah tanah adat dapat menunjuk kepada dua pengertian, yaitu: (1) Tanah adat dalam pengertian sebagai tanah "bekas milik adat"; (2) Tanah milik masyarakat hukum adat.

Penulis beranggapan bahwa tanah milik masyarakat hukum adat memiliki pengertian yang sama dengan tanah-tanah yang dikuasai oleh kesatuan masyarakat hukum adat (KMHA), dan mengenai ini juga telah diakui dalam Pasal 3 UUPA, serta dalam istilah terjemahan yang digunakan oleh Cornelis Van Vollenhoven, beschikkingrecht disebut juga dengan istilah hak pertuanan. (M. I. Arisaputra, 2011)

Ada beberapa jenis tongkonan berdasarkan peran pemiliknya dalam masyarakat Riyadi Ismanto dan Margareta Maria, 2020), yaitu: (1) Tongkonan Layuk (Maha tinggi/agung), merupakan bangunan pusat pemerintahan dan kekuasaan yang mengatur Tana Toraja; (2) Tongkonan Pekandoran (tongkonan kaprengesan), merupakan bangunan yang didirikan sebagai perwakilan dari, tongkonan layuk untuk 
mengatur pemerintahan adat di daerah/wilayah; (3) Tongkonan Batu a'riri, merupakan bangunan yang berfungsi sebagai ikatan dalam membina persatuan dan warisan keluarga.

Perbedaannya hanya pada jenis tongkonan layuk dan tongkonan pekandoran yang memiliki tiang tengah yang ditandai dengan hiasan kepala kerbau dan ayam. Secara umum adat istiadat dan tradisi pada masing-masing wilayah berasal dari sumber peradaban yang sama yaitu suku Toraja, namun pada pelaksanaanya terdapat perbedaan.

Pesatnya pembangunan sarana dan prasarana membuat nilai kebutuhan akan tanah terus meningkat, sehingga menjadikan tanah sangat bernilai ekonomis tinggi dan melemahkan nilainilai sosial-religiusnya. Kondisi tersebut berpengaruh terhadap pola pengelolaan tanah adat yang semula lebih bersifat komunal dan religius mengarah kepada pengelolaan yang bersifat individual untuk dimanfaatkan bagi kesejahteraan dan kepentingan bersama.

Program PTSL merupakan program pendaftaran tanah untuk pertama kali secara sistematis, yang sebelumnya terdapat program lain yang lebih dikenal dengan Program Nasional Agraria (PRONA) dan memiliki perbedaan konsep yaitu adanya kesadaran bahwa berdasarkan aspek yuridisnya tidak semua bidang tanah dapat diterbitkan sertifikatnya. (Wahyuni, 2017)

Pemerintah memberikan suatu program pendaftaran tanah kepada masyarakat yang didasarkan pada sembilan program program kerja, yang lebih kenal dengan nawa cita. Sebagai wujud dari salah satu butir dari program nawa cita tersebut pemerintah memberikan program pendaftaran tanah sistematis lengkap (PTSL) yang bertujuan untuk mendorong pelaksanaan landreform.
PTSL diawali dengan diterbitkannya Peraturan Menteri Agraria dan Tata Ruang Kepala Badan Pertanahan Nasional (Perkaban) Nomor 35 Tahun 2016 tentang Percepatan Pelaksanaan PTSL, yang mencabut Peraturan Menteri Agraria dan Tata Ruang Nomor 4 Tahun 2015 Tentang Program Nasional Agraria, Peraturan Menteri Agraria dan Tata Ruang Nomor 28 Tahun 2016 Tentang Percepatan Program Operasi Nasional Agraria Melalui Pendaftaran Tanah Sistematis yang dimana Program Operasi Nasional Agraria kurang bisa memenuhi kebutuhan masyarakat saat ini, untuk itu diperlukan percepatan lagi dalam memberikan kepastian hukum terhadap penegasan hak atas tanah dalam waktu cepat. (Rahmat Riardo, 2019)

Selanjutnya Peraturan Menteri Agraria dan Tata Ruang/Kepala Badan Pertanahan Nasional Nomor 35 Tahun 2016 Tentang Percepatan Pelaksanaan PTSL telah beberapa kali menegalami perubahan, terbaru dengan Peraturan Menteri Agraria dan Tata Ruang Kepala Kantor Pertanahan Nasional Nomor 12 Tahun 2017 Tentang Percepatan PTSL. Peraturan tersebut di atas diubah kembali menjadi Peraturan Menteri Agraria dan Tata Ruang/Kepala Badan Pertanahan Nasional Nomor 6 Tahun 2018 (Permen ATR/BPN No 6/2018). Pembaruan dari aturan terhadap PTSL terjadi karena aturan aturan yang terkait dengan PTSL sebelumnya masih memerlukan penyempurnaan substansi atau materi untuk menyesuaikan pada ketentuan peraturan perundang-undangan terkait pendaftaran tanah maupun ketentuan pertanahan lainnya.

Latar belakang diadakannya program PTSL ini karena Pemerintah masih menemukan banyak sekali tanah di Indonesia yang belum bersertifikat atau tidak memiliki sertifikat dan menurut Pasal 2 Ayat 2 Peraturan Menteri Agraria 
dan Tata Ruang/Kepala Badan Pertanahan Nasional Nomor 6 Tahun 2018 Tentang Pendaftaran Tanah Sistematis Lengkap (PTSL) bertujuan untuk memberikan kepastian hukum dan perlindungan hukum atas tanah yang dimiliki oleh masyarakat Indonesia. PTSL menaruh kesempatan bagi masyarakat yang belum mendaftarkan tanah miliknya yang berada di semua daerah Republik Indonesia pada satu desa atau kelurahan. Pensertifikatan tanah merupakan hal yang wajib dilakukan masyarakat untuk mendapatkan kepastian hukum dan bukti otentik dari kepemilikkan tanahnya. Program ini dilakukan oleh pemerintah Indonesia secara serentak yang terbagi atas pengumpulan, pengolahan, pembukuan, penyajian dan pemeliharaan data fisik serta pemberian bukti untuk bidang tanah yang sudah ada hak diatasnya.

Penulis berpendapat bahwa salah satu permasalahan dalam program PTSL, sebagaimana tertuang dalam Pasal 4 Ayat (2) Peraturan Menteri Agraria dan Tata Ruang/Kepala Badan Pertanahan Nasional Nomor 6 Tahun 2018 Tentang Pendaftaran Tanah Sistematis Lengkap (PTSL) yakni objek pendaftaran tanah sistematis lengkap (PTSL) meliputi seluruh bidang tanah tanpa terkecuali, baik bidang yang telah memiliki hak atas tanah maupun yang belum memiliki hak bidang atas tanah.

Pendaftaran tanah sistematis lengkap (PTSL) terhadap tanah tongkonan apabila didaftarkan, dapat menimbulkan berbagai permasalah diantaranya, siapakah yang akan menjadi pemegang hak atas tanah tongkonan tersebut, kemudian apabila telah didaftarkan apakah telah terjamin dan telah sesuai dengan tujuan dari UUPA dan terkhusus pada program PTSL itu sendiri, lebih lanjut dalam memenuhi persyaratan untuk didaftarkan yang memerlukan banyak syarat seperti persetujuan anggota rumpun keluarga yang lengkap dan tidak banyak anggota rumpun keluarga yang cukup antusias untuk mendaftarkan tanah mereka dengan tujuan memperjelas hak kepemilikan, (Darmini Roza, Laurensius Arliman S, 2017) dimana tanah tongkonan sendiri merupakan tanah yang dikuasai secara turun-temurun dan tidak dapat dibagibagikan atau dialihkan kepada pihak lain. Pelaksanaan program PTSL pada tahun 2017 lalu di Kabupaten Toraja Utara telah dilaksanakan dengan target 2.100 bidang tanah termasuk untuk tanah tongkonan, yang dimana baru sebanyak 1.850 bidang tanah telah terdaftar namun belum semua dari tanah terdaftar tersebut telah terbit sertifikat, sementara itu pemerintah menargetkan program PTSL dalam kurun waktu 2017-2025 harus dituntaskan secara keseluruhan pendaftaran dan pensertifikatannya sebanyak 126 juta bidang tanah di wilayah Indonesia. (D. A. Mujiburohman, 2018)

Mengingat bahwa tanah ulayat bukanlah objek pendaftaran tanah menurut Peraturan Pemerintah Nomor 24 Tahun 1997 tentang Pendaftaran Tanah, dan menurut ketentuan Pasal 5 UUPA yang mengakui mengakui eksistensi dari tanah hak ulayat, serta diperjelas dalam Pasal 1 Ayat 2 Peraturan Menteri Agraria Dan Tata Ruang/Kepala Badan Pertanahan Nasional Republik Indonesia Nomor 18 Tahun 2019 tentang Tata Cara Penatausahaan Tanah Ulayat Kesatuan Masyarakat Hukum Adat mengatur bahwa hak ulayat kesatuan masyarakat hukum adat bersifat komunal, yang mana dalam hal ini penulis berpendapat bahwa tanah tongkonan termasuk di dalamnya. Adanya kesenjangan antara ketentuan dan nilai-nilai adat dengan hukum positif yang penulis teliti terhadap tanah tongkonan di Kabupaten Toraja Utara yang ikut serta kedalam program PTSL yang apabila diterbitkannya sertifikat hak 
milik tanah ulayat kepada nama salah anggota keluarga atau rumpun keluarga tersebut, maka akan menghilangkan status ulayat kaum atas tanah tongkonan tersebut.

\section{METODE}

Tipe penelitian ini menggunakan tipe penelitian empiris dan menggunakan metode analisis kualitatif. yang merupakan suatu metode penelitian hukum yang berfungsi untuk dapat melihat hukum dalam artian nyata serta meneliti bagaimana bekerjanya hukum di lingkungan masyarakat. (Irwansyah, 2020)

Penelitian hukum empiris dapat juga dikatakan sebagai penelitian hukum sosiologis, penelitian ini hendak mengadakan pengukuran terhadap peraturan perundang-undangan tertentu mengenai efektivitasnya sehingga dapat mengkaji berkerjanya hukum di masyarakat dari tingkat efektivitas, kepatuhan implemtasi aturan hukum, peranan lembaga atau institusi dalam penegakan hukum, serta pengaruh hukum dalam masalah sosial ataupun pengaruh masalah sosial terhadap hukum.

Lokasi penelitian ini dilakukan di Kabupaten Toraja Utara, lebih tepatnya di Kantor Badan Pertanahan Nasional Kabupaten Toraja Utara. Pertimbangan melakukan penelitian di daerah tersebut karena sesuai dengan objek penelitian yang akan diteliti, serta penulis dapat memperoleh bahan-bahan dan data-data terkait penelitian.

Populasi yang digunakan dalam penelitian ini adalah lembang yang terdaftar sebagai obyek pendaftaran tanah sistematis lengkap oleh BPN, anggota tongkonan atau rumpun keluarga, Pemerintah Kabupaten Toraja Utara, Badan Pertanahan Nasional Kabupaten Toraja Utara; sementara untuk teknik pengambilan sampel dalam penelitian menggunakan teknik purposive sampling, yang merupakan penarikan sampel bertujuan yang dilakukan dengan cara mengambil sampel yang didasarkan pada tujuan tertentu. Adapun sampel terdiri atas: a) kantor Badan Pertanahan Nasional Kabupaten Toraja Utara, b) Pemerintah Kabupaten Toraja Utara, c) anggota masyarakat tongkonan.

Jenis dan data yang digunakan dalam penelitian ini adalah: a) data primer merupakan sekumpulan informasi yang diperoleh peneliti langsung dari lokasi penelitian melalui wawancara dengan responden yang berkaitan langsung dengan objek penelitian di Kabupaten Toraja Utara; b) data sekunder merupakan bahan-bahan yang erat dengan hubungannya dengan bahan hukum primer dan dapat membantu menganalisa dan memahami bahan hukum primer, yang diperoleh dari bukubuku atau penelitian kepustakaan dan peraturan perundang-undangan yang berkaitan dengan objek penelitian ini.

Dalam penelitian ini teknik pengumpulan data yang digunakan adalah: (a) Wawancara; Metode pengumpulan data dengan cara mengajukan pertanyaan secara lisan kepada responden, guna mendapatkan data yang akurat dan dapat dipertanggung jawabkan. (b) Dokumentasi atau studi kepustakaan; Metode pengumpullan berbagai dokumen yang berkaitan dengan masalah penelitian, yang kemudian dianalisis untuk memperoleh kejelasan penyelesaian masalah, kemudian ditarik kesimpulan secara deduktif yaitu dari hal yang bersifat umum menuju hal yang bersifat khusus. (Lexy J. Moleong, 2017)

Setelah dilakukan pengumpulan data, maka kemudian data yang ada tersebut di analisis menggunakan metode kualitatif, yaitu menganalisis data-data yang diperoleh tersebut dengan teoriteori, kaidah-kaidah maupaun asas-asas hukum yang terkait dengan permasalahan 
yang diteliti, sehingga dapat ditarik jawaban atas permasalahan yang diteliti.

\section{HASIL DAN PEMBAHASAN}

\section{Kepemilikkan Tanah Tongkonan yang Didaftarkan Melalui Program Pendaftaran Sistematis Lengkap (PTSL)}

Tanah tongkonan merupakan tanah adat yang kepemilikkannya dikuasai sekelompok anggota atau rumpun keluarga dimana pengaturan, penguasaan, dan pengunaannya ditentukan menurut norma-norma dan aturan-aturan adat yang berlaku diantara anggota atau rumpun keluarga itu sendiri. (Bunshar Muhammad, 2004) Hak ulayat kesatuan para rakyat hukum adat yang memiliki sifat komunal hal tersebut dapat diartikan sebagai penguasaan tanah paling tinggi tanah adat yang memiliki 2 (dua) unsur yang berkaitan antara hukum keperdataan dan hukum publik, yang berdampak pada tidak terpisahkannya dengan rakyat yang melingkupi hukum adat itu sendiri, ialah sekelompok masyarakat yang mempunyai kekayaan tersendiri selain kekayaan perseorangan, memiliki batas wilayah tertentu, dan memiliki kekuasaan tertentu. Pasal 5 UUPA menegaskan jika hukum adat merupakan suatu fondasi dari hukum agraria yang telah dibuat atau terbaru, yang sekaligus menjadi dasar pengakuan hak ulayat masyarakat hukum adat.

Suatu hak ulayat yang dimiliki oleh para rakyat hukum adat adalah sebuah rancangan kewenangan serta kewajiban pada rakyat hukum adat yang tertentu mengenai beberapa letak wilayah yang dijadikan sebagai ulayatnya berdasarkan lingkungan hidup yang dimana didalamnya meliputi pemanfaatan sumber daya alam pada wilayah tertentu. Hal tersebut menunjukkan sebuah hubungan yang dibangun antara cara para masyarakat dengan hukum dan tanahnya dijadikan sebagai kompetensi komunalistik yang memiliki ciri tertentu, karena rakyat hukum adat mempunyai sebuah wewenang dan kekuasaan dalam mengelola tanah dengan isinya.

Terdapat beberapa kriteria keberadaan tanah tongkonan yang ditandai oleh: (a) Asas tanah tongkonan adalah asas terpisah (Horizontal splitzing) yaitu terpisahnya antara tanah dengan segala sesuatu yang ada diatasnya. Tanah tongkonan tidak boleh dijual, dihibahkan atau dilepaskan kepada pihak diluar rumpun keluarga. (b) Tanah tongkonan dikelola oleh to ma'kampai tongkonan (salah satu anggota rumpun keluarga yang mendapat manat/ditunjuk untuk menjaga atau tinggal di rumah tongkonan) dan digunakan untuk kepentingan seluruh rumpun keluarga dalam naungan to ma'kampai tongkonan tersebut; semua rumpun keluarga berhak untuk mengolah, mencari nafkah dan memanfaatkan tanah tongkonan, tetapi tidak berhak memilikinya, dikarenakan pemilik tanah tongkonan sesunguhnya adalah leluhur. (c) Pemindahan tanah tongkonan, hanya dalam bentuk gadai, setelah disepakati oleh seluruh anggota tongkonan melalui suatu musyawarah mufakat dan diutamakan kepada anggota tongkonan terdekat terlebih dahulu.

Masyarakat hukum adat di Kabupaten Toraja Utara memahami dan menghayati betul mengenai tanah tongkonan, memahami mengenai sebuah hak yang perlu diterima dan kewajiban yang perlu ditunaikan atas tanah tongkonan yang di mana dijadikan individu masyarakat hukum adat hanya sebagai penopang pada adat. Tanah tongkonan adalah tanah/wilayah yang dimiliki atau dikuasai oleh seluruh anggota tongkonan yang terhimpun dalam suatu ikatan keturunan (geneologis), berupa rumah tongkonan 
dan perangkatnya, hutan tongkonan (kombong) dan hutan (pangala'), tanah kering, tanah basah/sawah, tanah pekuburan. Sedangkan tanah milik pribadi hanya berupa kebun atau sawah yang biasanya didapat karena pemberian (wasiat) ataupun usaha. Dapat diketahui bahwa eksistensi tanah tongkonan sebagai bagian dari tanah ulayat yang menurut kenyataannya masih ada. Sejalan dengan hasil penelitian, Pemerintah Kabupaten Toraja Utara mengakui dan menetapkan keberadaan masyarakat hukum adat dengan menciptakan suatu ketetapan Peraturan Daerah Kabupaten Toraja Utara Nomor 1 Tahun 2019 yang di dalamnya mengenai Tentang Pengakuan Dan Perlindungan Hak Masyarakat Hukum Adat.

Berdasarkan hasil penelitian dilapangan, penulis mendapati alasan anggota tanah tongkonan untuk mendaftarkan tanah tongkonan, antara lain:

a) Rumpun keluarga ingin mendapatkan perlindungan dan kepastian hukum atas tanah mereka.

Dengan adanya pendaftaran tanah tongkonan diharapkan dapat memberikan kepastian hukum bagi kepemilikan ulayat kaum. Kepastian hukum yang dimaksud dengan kegiatan registrasi pedalaman, misalnya mengenai kejelasan hukum yang berkaitan dengan individu maupun badan yang memegang suatu hak, serta kepastian hukum yang menunjukkan lokasi, batas, dan tentu saja luas bidang tanah yang berhak menjadi hak dan kepastian hukum tentang hak-hak yang dibutuhkan mereka. (Aartje Tehupeiory, 2017)

Sebagaimana dijelaskan dalam Pasal 28 D ayat (1) Undang-Undang Dasar Negara Republik Indonesia Tahun 1945, dengan jelas disebutkan jika setiap individu memiliki hak dan pengakuan atas jaminan maupun dukungan dan kepastian yang berkaitan dengan hukum, khususnya para WNI mengenai tanah yang dimiliki di Indonesia yang sifatnya tidak bisa diganggu gugat secara sewenang-wenang oleh siapa saja. Serta Pasal $28 \mathrm{H}$ ayat (4) Undang-Undang Dasar Negara Republik Indonesia Tahun 1945 yang menyatakan bahwa seluruh wilayah yang letaknya berada di Indonesia adalah suatu kesatuan yang meliputi bangsa yang memiliki hakikat persatuan sebagai bangsa Indonesia. Terdapat keterkaitan hubungan yang terjalin oleh bangsa indonesia pada eksistensi bumi air, dan angkasa yang dapat memiliki suatu sifat kekal dan diuraikan pada Pasal 1 ayat (2) UUPA. Pendaftaran tanah memiliki tujuan yang diatur pada Pasal 3 Peraturan Pemerintah Nomor 24 Tahun 1997 mengenai pendaftaran atas hak tanah yaitu itu agar terjamin kejelasan hukum dan perlindungan yang diberikan oleh hukum bagi siapapun yang memiliki keterkaitan dalam memegang bidang tanah, serta suatu hak lainnya yang dimiliki oleh pemegang hak berkaitan dalam suatu sertifikat yang diberikan kepada mereka. (Adrian Sutedi, 2008).

Dengan pernyataan tersebut dapat disimpulkan bahwa dibutuhkannya suatu pendaftaran mengenai tanah agar mendapatkan perlindungan serta kepastian hukum yang dimiliki bagi siapapun pemegang bidangnya.

b) Pemindah tanganan hak (dijual) sebagian tanah tongkonan kepada pihak yang lain.

Perlu diperhatikan mengenai kepentingan para calon pembeli maupun calon kreditur yang ditujukan untuk mempermudah dalam mendapatkan sebuah data yang valid. Pada dasarnya tanah tongkonan tidak dapat dialihkan (dijual) kepada pihak lain, melainkan hanya dapat digadaikan, karena bersifat kolektif (turun temurun atau geologis). Adapun alasan digadaikan karena keadaan darurat/mendesak. Namun jika 
dilihat pada masa sekarang tidak ada alasan yang tepat menjual tanah tongkonan kepada orang lain, developer ataupun perusahaan untuk pembangunan.

Pemindah-tanganan tanah ulayat kaum juga disebabkan karena banyaknya investor yang menjanjikan dengan sistem bagi hasil dalam pembangunan rumah ataupun Perseroan, dan disebabkan karena semakin bertambahnya jumlah masyarakat yang datang dari luar daerah, sehingga kebutuhan akan tanah juga bertambah terutama bagi investor. Berdasarkan Hasil wawancara dengan Kepala Lingkungan Keluarahan Palawa menyebutkan bahwa latar belakang untuk menjual tanah ulayat kaum pada masa lampau tersebut untuk membiayai keperluan usaha atau untuk biaya anak atau rumpun tongkonan bersekolah di tanah rantau. Dalam hukum adat pengalihan tanah adalah hukum properti, khususnya hukum agraria, bukan hukum perikatan, hal ini disebabkan karena (Adrian Sutedi, 2008): (1) Suatu kegiatan dalam jual maupun Membeli tanah dalam hukum adat ialah tidak dapat dikatakan sebagai kesepakatan karena para pemerannya tidak diwajibkan para pihak tertentu untuk melakukan jual-beli. (2) Kegiatan dalam jual maupun Membeli tanah dalam hukum adat tidak menciptakan pembunuhan mengenai hak dan kewajiban mengenai tanah. Jadi di saat para pembeli telah memberikan bayaran sebagian dari harga tanah namun pembeli tidak membayar akan sisanya sehingga penjual pun tidak memiliki hak dalam menuntut atas jual beli tanah yang telah disebutkan.

Transaksi yang dilakukan dalam kegiatan jual beli tanah mengenai sistem hukum adat memiliki beberapa komponen, (Adrian Sutedi, 2008) yaitu: (a) Pemindahan mengenai hak atas tanah sebagai suatu bayaran yang tunai yang dijadikan sebagai hak dalam mendapatkan kembali tanah setelah membayar sebagian uang yang telah diberikan; (b) Pemindahan mengenai hak atas tanah yang mendasar dengan bayaran tunai namun tidak dapat hak dalam membeli kembali; (c) Pemindahan hak mengenai tanah yang Berdasarkan kesepakatan pembayaran jika setelah beberapa tahun panen dan tidak terdapat suatu aksi hukum tertentu maka tanah tersebut dapat kembali.

Untuk mempermudah transaksi jual beli tanah, perlu didaftarkan atau dikonversikan tanah ulayat kaum tersebut menjadi hak milik, dengan demikian mempermudah proses jual beli dan proses pengelolaan yang memiliki keterkaitan dengan pendataan yang diakumulasikan bersifat fisik dan data yuridis dalam suatu bidang yang memiliki keterkaitan dengan pertanahan. Karena jika terjadi peralihan (illegal) atau jual beli tanah adat, maka aturan adat di kawasan tersebut tidak berlaku lagi.

Tanah tongkonan adalah tanah ulayat yang bersifat komunal (milik bersama) yang mempunyai berbagai macam bidang tanah dan hal tersebut secara berkesinambungan berfokus pada pengawasan to ma'kampai tongkonan. UUPA tidak memiliki status yang jelas mengenai hak komunal kecuali disebutkan jika yang dimaksud sebagai hak ulayat merupakan beschikkingrecht yang terdapat pada literatur hukum adat. Hak ulayat yang diyakini sebagai julukan dari yuridis teknis merupakan suatu hak yang telah tertanam kan kan pada kompetensi rakyat hukum adat yang didalamnya memiliki wewenang dalam pengaturan serta pemeliharaan tanah yang isinya, daya jual pihak dalam maupun pihak luar. Maka dengan itu hak ulayat memberikan sebuah gambaran mengenai hubungan hukum yang dibangun antara masyarakat hukum serta tanah tersebut. Hak ulayat dapat memiliki beberapa kewenangan, yaitu: (a) Suatu pengaturan mengenai penggunaan lahan 
yang meliputi pemukiman, pertanian dan sebagainya, mengenai ketersediaan dalam pembangunan pemukiman baru maupun sawah dan sebagainya hingga pengelolaan lahan. (c) Memiliki wewenang dalam memberikan aturan maupun menentukan hubungan hukum yang dibangun antara masyarakat dengan tanah dimana hak tersebut diberikan kepada subjek tertentu. (d) Dapat mengatur serta menentukan hubungan hukum yang dijalin antara masyarakat dan perbuatan hukum yang didalamnya memiliki keterkaitan dengan tanah meliputi sebuah kegiatan jual-beli, warisan dan sebagainya.

Alasan rumpun keluarga dalam mengkonversikan tanah tongkonan adalah untuk menegaskan tentang hak atau kepemilikan suatu rumpun keluarga atas tanah tongkonan mereka, sehingga jelas statusnya menjadi tetap hak milik rumpun tongkonan, namun banyak juga yang tidak ingin mengkonversikan tanah tongkonan dikarenakan tanah tongkonan merupakan milik banyak rumpun keluarga yang jika dikonversikan akan susah untuk mengumpulkan seluruh rumpun keluarga, belum juga jika ada persitegangan antar keluarga jika akan didaftarkan.

Peran perangkat adat dalam suatu kelompok masyarakat hukum adat sebagai pengatur mengenai hubungan hukum antar anggota masyarakat dan hubungan hukum keluar, yang dimana perangkat adat diisi oleh tetua-tua adat atau tokoh-tokoh adat yang berjumlah 7 (tujuh orang) yang disebut hakim adat pendamai, yang dipilih oleh kepala lembang (desa), kepala lingkungan, kepala kelurahan beserta masyarakat, dengan persyaratan harus memiliki pengetahuan dan wawasan mengenai batas-batas wilayah tanah tongkonan di wilayah kecamatan atau kelurahan di daerahnya. Perangkat adat inilah yang mengambil keputusan melalui rapat adat baik untuk atas nama persekutuan maupun atas nama perseorangan mengenai tanah tongkonan di wilayahnya.

Penguasaan tanah pada rakyat hukum adat Toraja yang di mana telah diberikan sebuah aturan ketentuanketentuan adat Toraja yang nyata-nyata masih berkembang peserta hadir dan dihormati oleh anggota masyarakat hukum adatnya secara turun-temurun. Penguasaan tanah bagi masyarakat hukum adat, dimanapun selalu keberadaannya, batas-batas dan luasnya, diakui dan diterima anggota masyarakat berdasarkan kesepakatan tidak tertulis.

Berbeda dengan kebiasaan seperti itu, UUPA menghendaki melalui pasalpasalnya agar adanya bukti hak atas tanah yang tertulis, agar dapat ditentukan subjek dan objeknya yang pasti dalam rangka untuk mendapatkan jaminan kepastian hukum atas tanah. Dari penjelasan itu nampaklah bahwa anggota masyarakat hukum adat dihadapkan kepada 2 (dua) pilihan yaitu berbuat atau tidak berbuat untuk mendaftarkan tanah tongkonannya. Dari hasil penelitian penulis mendapati bahwa ada kecendrungan salah satu anggota tongkonan untuk mendaftarkan tanahnya.

Hal ini ditunjukkan bahwa dari waktu ke waktu selau terjadi penambahan jumlah tanah tongkonan yang didaftarkan, namun tidak dapat terealisasikan dikarenakan mendapat pertentangan dari rumpun keluarga tongkonan yang lain. Badan Pertanahan Nasional Kabupaten Toraja Utara sendiri berpendapat bahwa, akan lebih baik jika tanah tongkonan itu didaftarkan agar menjamin kepastian hukum dan tertib administrasi pertanahan yang bertujuan untuk kemajuan daerah. 


\section{Bentuk Pendaftaran Tanah Sistematis Lengkap (PTSL) Terhadap Tanah Tongkonan}

Pendaftaran tanah atau yang dikenal dengan kadaster adalah istilah teknis untuk pencatatan. Kadaster yang didapat dari bahasa Latin yang memiliki arti kapi stroom yaitu Register atau capite dimana hal tersebut dijadikan sebagai istilah pada zaman Romawi dalam mengurus segala hal yang terkait dengan pajak tanah. Istilah berikut digunakan untuk sebuah pendaftaran hak atas tanah yang memiliki arti pendaftaran pada pemerintah untuk semua tanah ataupun barang yang tidak bergerak khususnya dalam keperluan yang menyangkut hal perpajakan serta perubahan hak milik dan (Andi Hamzah, Kamus Hukum, dalam A. Suriyaman Mustari Pide, 2009) maka dari itu kadaster adalah instrumen yang paling tepat untuk memberikan ilustrasi serta analisis mengenai tanah yang berfungsi untuk wujud pencatatan publik hak mengenai tanah secara berkesinambungan. (A. P. Parlindungan, dalam A. Suriyaman Mustari Pide, 2009)

Pasal 2 UUPA mengatur 3 (tiga) fungsi pokok agraria yang harus dilaksanakan oleh negara Indonesia hal ini Badan Pertanahan Nasional, yaitu: a) Dapat mengelola serta memelihara hal yang berkaitan dengan kegunaan, ketersediaan dan pengelolaan bumi, air maupun ruang angkasa; b) Suatu aturan yang ditetapkan untuk mengatur hubungan hukum yang dijalin oleh manusia dengan bumi, air dan ruang angkasa; c) menetapkan dan mengeloka hubungan hukum yang terjalin antara manusia dengan perbuatan hukum yang didalamnya meliputi bumi, air, dan ruang angkasa.

Melalui pasal 33 UUD NRI 1945 dikeluarkan sebuah kewenangan atribusi yang ditujukan untuk negara dalam hakikatnya mengatur penguasaan, peruntukkan dan pemanfaatan. Dengan berdasarkan Keputusan Presiden Nomor 26 Tahun 1988 mengenai Badan Pertanahan Nasional, Badan Pertanahan Nasional hadir sebagai suatu lembaga pemerintah yang tidak termasuk pada departemen diciptakan untuk mengatur serta menangani hal yang menyangkut bidang pertanahan, maka dari itu itu dibuatlah suatu Peraturan Presiden Republik Indonesia Nomor 10 Tahun 2006 yang fungsinya adalah untuk memperkuat kelembagaan Badan Pertanahan Nasional Republik Indonesia, dimana hal tersebut telah diubah dengan Peraturan Presiden Republik Indonesia Nomor 63 Tahun 2013 mengenai Badan Pertanahan Nasional. Serta Peraturan Pemerintah Nomor 24 Tahun 1997 tentang Pendaftaran Tanah yang mengelola mengenai terlaksananya pendaftaran tanah dilakukan oleh Badan Pertanahan Nasional, sehingga BPN memiliki legitimasi dalam hal yang menyangkut dengan pendaftaran tanah.

Pendaftaran tanah sistematis (PTSL) yang menjadikan tanah tongkonan sebagai objek pendaftaran, dapat merubah status serta hak jika belum berlakunya UUPA yang dijadikan sebagai status baru dalam menilai sebuah pengakuan yang hadir berdasarkan pengakuan yang bersangkutan dengan hak pemilik dan telah dijamin oleh status baru yang telah dijamin oleh bangsa Indonesia. Hal tersebut memiliki keterkaitan dengan teori kepastian hukum serta perlindungan hukum yang digunakan oleh penulis dalam mengevaluasi maupun menganalisis sebuah penelitian ini dalam mengetahui implikasi dari pendaftaran tanah Tongkonan.

Mekanisme untuk mendaftarkan tanah tongkonan ada 2 (dua) tahapan yaitu: (a) Tingkat adat (musyawarah rumpun keluarga tongkonan), tahapan ini bertujuan untuk mendapatkan 
persetujuan dari seluruh rumpun keluarga tongkonan; (b) Tingkat Instansi Pemerintah, pada tahapan ini berkaitan serta memiliki hubungan dengan kegiatan awal pada tingkat lingkungan, Lembang (desa), Kelurahan, Kecamatan, BPN (terbitnya sertifikat).

Tabel 1. Grafik Pelaksanaan Dan Target PTSL Di Kabupaten Toraja Utara Dari Tahun Ke Tahun

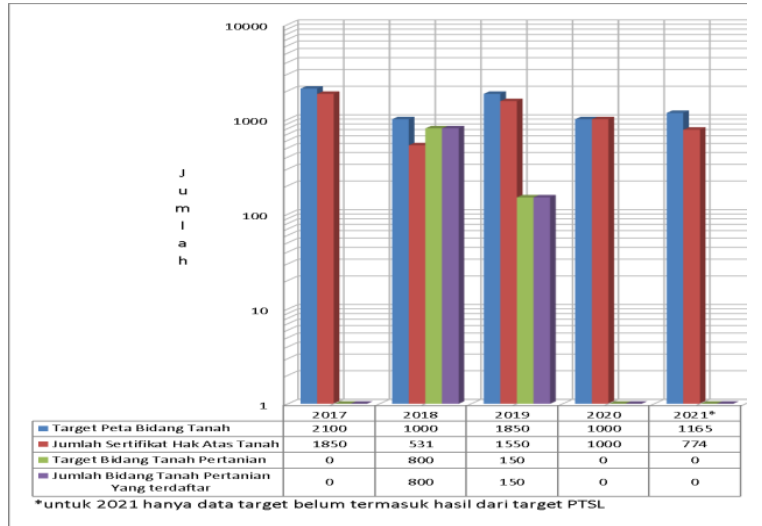

Sumber: Badan Pertanahan Nasional Kabupaten Toraja Utara

Berdasarkan program PTSL, dalam suatu proses konversi dan pendaftaran tanah Tongkonan memiliki suatu percepatan yang dimana hal tersebut dapat mempermudah masyarakatnya. Adanya suatu perbedaan mengenai pendaftaran tanah Tongkonan jika melewati jalur luar dari PTSL dan PTSL yang secara general memiliki suatu tahapan yang dilakukan pada awal seperti sosialisasi, menentukan sebuah lokasi, rancangan kepegawaian serta penciptaan panitia ajudikasi percepatan, satuan tugas yuridis, pelatihan dan penyuluhan untuk instansi yang bersangkutan dengan pihak yang terlibat ternyata tidak jauh berbeda dengan program agraria nasional. Namun, di PTSL jika ingin mengsertifikasi lahan maka perlu satu hamparan sedangkan jika program agraria nasional dapat berpencar-pencar. Pada tahapan berikut dapat disimpulkan bahwa pelaksanaan konversi secara otomatis dan pendaftaran lahan
Tongkonan dapat dengan mudah diakses karena adanya suatu penghapusan mengenai biaya yang biasanya dikeluarkan untuk awal pendaftaran dan biaya Pengukuran lainnya yang biasanya perlu dibayar. Dengan hadirnya eksistensi panitia ajudikasi serta satuan tugas yuridis yang membantu dalam mempermudah akses para masyarakat dalam mengaktifkan proses pemeliharaan.

Suatu anggaran yang dikeluarkan di PTSL memiliki prinsip yang berisi bermuatan $100 \%$ jika kepada seluruh bidang terdaftarkan dengan status kategori (K1), yang merupakan suatu bidang tanah di dalamnya terdapat data yuridis yang memenuhi seluruh persyaratan dengan tujuan untuk menerbangkan sertifikat mengenai hak dari tanah tersebut. Selain itu, terdapat beberapa target yang perlu dilaksanakan oleh Badan Pertahanan Nasional pada setiap kota maupun kabupaten yang berada di wilayah sebut agar pelaksanaan program ini terlaksana dengan cepat.

Adanya suatu perbedaan yang terletak pada tahap yang kedua mengenai kegiatan dalam suatu instansi yang dikelola pemerintah, di mana tahapan yang seharusnya hadir kontribusi dari masyarakat yang mengajukan permohonan hak mengenai tanah secara nyata menggunakan jalur PTSL, namun tidak berkaitan langsung karena adanya suatu pemeran pengganti yang dilakoni oleh para panitia ajudikasi dan Satgas yuridis dengan sebuah pengakumulasian data secara nyata. Sedangkan jika dibandingkan dengan Tahapan pertama pada tingkat hukum adat perlu melewati sebuah jalur yang memiliki kondisi sama dengan keadaan yang telah dijelaskan sebelumnya.

Perbedaan lainnya ialah proses waktu mengenai pengumuman sertifikat yang telah diterbitkan oleh Badan Pertahanan Nasional dalam kurun waktu 
14 Hari, namun memiliki perbedaan jika dikorelasikan antara program pendaftaran tanah selaij PTSL bisa memakan waktu selama 60 hari, seluruhnya telah diatur dalam Peraturan Pemerintah Nomor 24 Tahun 1997 mengenai Pertanahan. Registrasi. Jangka waktu yang lebih singkat dianggap tidak merugikan untuk masyarakat yang keberatan dengan sebuah proses PTSL jika terdapat beberapa pihak yang bersangkutan merasa keberatan dengan program tersebut maka dapat memberikan sebuah pernyataan keberatan melalui ketua panitia ajudikasi PTSL dalam kurun waktu 14 Hari Saat pemberitahuan informasi yang berkaitan dengan akumulasi data fisik serta data yang dikelola oleh yuridis, mengenai akurasi dari materi data fisik dan data yuridis dapat dipertanggungjawabkan oleh pemohon PTSL. Misalnya, jika pada tahap pengumuman telah berakhir dalam kurun waktu 14 hari maka jika pihak yang saling berkaitan merasa rugi dapat memiliki hak untuk melaporkan tindakan tersebut ke Pengadilan Tata Usaha Negara atau Pengadilan Negeri. Mengenai sebuah dilaksanakannya pada lapangan memiliki berbagai macam kendala atau rintangan yang dihadapi oleh para petugas BPN dan masyarakat maupun pihak lainnya, hal tersebut ialah minimnya partisipasi fasilitator dari sebuah desa yang tidak turun kelapangan, serta domisili yang berbeda dengan pemilik tanah dapat mempersulit pengakumulasian data yuridis.

Menurut suatu wakil masyarakat yang ikut berkontribusi dalam program PTSL menyebutkan bahwa dalam program tidak mengalami kendala ataupun rintangan yang serius untuk mengurus sertifikat tanah, baik hal tersebut memenuhi seluruh persyaratan yang perlu dibereskan maupun suatu biaya pelaksanaan yang sifatnya tidak perlu dibayar Karena bebas biaya jika persyaratan pemohon seluruhnya sesuai dengan ketentuan dan tidak terlibat pada perselisihan.

Negara memberikan jalan penguasaan tanah adat atau tanah ulayat oleh para rakyat adat melalui penerbitan mengenai Peraturan Menteri Agraria dan Tata Ruang/Kepala Badan Pertanahan Nasional Nomor 6 Tahun 2018 yang berisikan Pendaftaran Tanah Sistematis Lengkap (PTSL) namun hal tersebut bertentangan dengan Pasal 4 Peraturan Menteri Agraria Dan Tata Ruang/Kepala BPN Nomor 18 Tahun 2019 tentang Tata Cara Penatausahaan Tanah Ulayat Kesatuan Masyarakat Hukum Adat, dan ketentuan Peraturan Daerah Kabupaten Toraja Utara Nomor 1 Tahun 2019 Tentang Pengakuan Dan Perlindungan Hak Masyarakat Hukum Adat yang di dalamnya mengelola pemeliharaan tentang berlakunya sebuah Pengakuan hak ulayat kesatuan para rakyat hukum adat. Maka dengan itu diterbitkan suatu Peraturan Menteri Agraria dan Tata Ruang/Kepala BPN Nomor 18 Tahun 2019 tentang Tata Cara Penatausahaan Tanah Ulayat Kesatuan Masyarakat Hukum Adat.

Penulis memiliki pendapat jika tanah Tongkonan yang terkait pada hak ulayat Kesatuan masyarakat adat, (dalam Pasal 1 Ayat (2) Peraturan Menteri Agraria Dan Tata Ruang/Kepala BPN Nomor 18 Tahun 2019 tentang Tata Cara Penatausahaan Tanah Ulayat Kesatuan Masyarakat Hukum Adat) sebaiknya tidak digunakan sebagai objek yang berasal dari pendaftaran tanah sistematis lengkap (PTSL) disebabkan karena tanah Tongkonan dapat dengan mudah mengalami terkonversi menjadi sebuah hak milik. Sebaliknya, tanah Tongkonan dapat dikokohkan melewati suatu ketetapan atau hal yang mengesahkan dan tertulis oleh pemerintah daerah mengenai eksistensinya. 


\section{PENUTUP}

$\begin{array}{ccc}\text { Mengenai rangakaian cara } & \begin{array}{c}\text { car } \\ \text { pelaksanaan Pendaftaran }\end{array} \text { Tanah }\end{array}$

Sistematis Lengkap (PTSL) dengan melewati sebuah konsep sosialisasi serta pengarahan, akumulasi data yuridis oleh satuan tugas yuridis, penggarapan dan verifikasi mengenai suatu data, dan penyelidikan mengenai tanah, pemberitahuan, dan suatu terbitan mengenai keputusan aturan dan penekanan hak, pendataan , dan pemberian sertifikat. Tanah tongkonan yang tergolong dalam kluster 1 (K1) atau informasi yang lengkap dan tanpa masalah dapat terdaftarkan secara gratis dalam rentang waktu yang cukup singkat.

Tanah tongkonan sebagai tanah ulayat kaum merupakan warisan pusaka, jika dikatakan para pemegang hak pada umumnya dipilih berdasarkan suatu sepakat yang telah disetujui seluruh anggota rumpun yang secara general dikelola oleh to ma'kampai tongkonan, tetapi ada juga pemegang sertifikat yang bukan to ma'kampai tongkonan, mereka bisa anggota rumpun lainnya yang diyakini terpercaya dalam mewakili dan dan tentunya Berdasarkan kesepakatan bersama. Proses konversi tanah tongkonan menjadi hak milik melalui program PTSL di Kabupaten Toraja Utara, harus mendapatkan persetujuan anggota rumpun keluarga melalui surat perjanjian keluarga yang ditandatangani oleh seluruh rumpun keluarga.

\section{DAFTAR PUSTAKA}

Aartje, Tehupeiory. 2017. Pentingnya Pendaftaran Tanah di Indonesia. Jakarta: Raih Asa Sukses.

Cris Lunnay dan Herman Soesangobeng. 1998. Status Reformasi Pertanahan dalam UndangUndang Pokok Agraria dan
Proyek

Administrasi

Pertanahan dengan Perspektif Sebesar-besarnya Kemakmuran Rakyat. Seminar Nasional Pertanahan. Bandung.

D. A. Mujiburohman. 2018. Potensi Permasalahan Pendaftaran Tanah Sistematis Lengkap (PTSL), BHUMI: Jurnal Agraria dan Pertanahan. Vol. 4 No. 1

Darmini Roza, Laurensius Arliman S. 2017. Peran Badan Permusyawaratan Desa Di Dalam Pembangunan Desa Dan Pengawasan Keuangan Desa. Padjadjaran Journal of Law. Vol. 4 No. 3.

Farida Patittingi. 2011. Penegasan Alas Hak Penguasaan Fisik Turuntemurun Dalam Praktik Pendaftaran Tanah. Jurnal Amanna Gappa. Vol. 19. No. 4.

Irma Devita Purnamasari. Cara Penyertifikatan Tanah Adat. https://www.hukumonline.com/ klinik/detail/ulasan/lt537ac3b73 7835/cara-penyertifikatantanah-adat/ (diakses 08 Juli 2020).

Irwansyah. 2020. Penelitian Hukum: Pilihan Metode dan Praktik Penulisan Artikel. Yogyakarta: Mirra Buana Media.

M. I. Arisaputra. 2011. Status Kepemilikkan Dan Fungsi Tanah Dalam Persekutuan Hidup Masyarakat Adat. Jurnal Ammana Gappa. Vol. 19. No. 4. Maria Farida Naibaho. 2015. Pengakuan Penguasaan dan Pendudukan Tanpa Alas Hak Kepemilikkan Yang Berakibat Sengketa; Studi Kasus Putusan MA No. 2511/K/PDT/1995 Tanggal 09 September 1997. Jurnal Universitas Sumatera Utara, Vol. VIII. 
Muhammad Ilham Saputra dan Sri Wildan Ainun Mardiah. 2019. Kedudukan Hukum tanah Adat dalam Pengembangan Administrasi Pertanahan di Indonesia: Studi Komparartif. Jurnal Amanna Gappa. Vol. 27 No. 2.

Muhammad, Bunshar. 2004. PokokPokok Hukum Adat. Jakarta: Pradnya Paramita.

Rahmat Riardo. 2019. Konversi Hak Atas Tanah Ulayat Kaum Menjadi Hak Milik Melalui Program Pendaftaran Tanah Sistematis Lengkap di Kota Solok. Soumatera Law Review. Vol. 2 No. 2.

Riyadi Ismanto dan Margareta Maria. 2020. Rumah Tongkonan Toraja Sebagai Ekspresi Estetika Dan Citra Arsitektural. Laporan Akhir Penelitian Fakultas Teknik Universitas Kristen Indonesia.

http://repository.uki.ac.id/2123/ (diakses 09 September 2020).

Suriyaman Mustari Pide, A. 2009. Quo Vadis Pendaftaran Tanah. Makassar: PUKAP-Indonesia.

Sutedi, Adrian. 2008. Peralihan Hak Atas

Tanah dan Pendaftarannya. Jakarta: Sinar Grafika.

Wahyuni. 2017. Problematika Pendaftaran Tanah Sistematis Lengkap dan Alternatif Penyelesaiannya (Studi Kasus di Provinsi Sumatera Utara). Puslitbang Kementrian ATR/BPN Puslitbang Kementrian ATR/BPN.

Undang-Undang Dasar Negara Republik Indonesia Tahun 1945.

Undang-Undang Nomor 5 Tahun 1960 Tentang Peraturan Dasar PokokPokok Agraria (UUPA).
Peraturan Pemerintah Nomor 24 Tahun 1997 tentang Pendaftaran Tanah.

Instruksi Presiden Nomor 2 Tahun 2018 tentang Percepatan Pendaftaran Tanah Sistematis Lengkap di Seluruh Wilayah Republik Indonesia.

Peraturan Daerah Kabupaten Toraja Utara Nomor 1 Tahun 2019 Tentang Pengakuan Dan Perlindungan Hak Masyarakat Hukum Adat.

Mahkamah Konstitusi Republik Indonesia, Risalah Sidang Perkara Nomor 31/PUU-V/2007 prihal Pengujian UndangUndang Nomor 31 Tahun 2007 tentang Pembentukan Kota Tual di Provinsi Maluku terhadap Undang-undang Dasar Negara Republik Indonesia 1945, Acara Pengucapan Putusan, Jakarta 18 Juni 2008.

Peraturan Menteri Negara Agraria/Kepala Badan Pertanahan Nasional Nomor 3 Tahun 1997 Tentang Ketentuan Pelaksanaan Peraturan Pemerintah Nomor 24 Tahun 1997 Tentang Pendaftaran Tanah.

Peraturan Menteri Agraria dan Tata Ruang/Kepala Badan Pertanahan Nasional Nomor 6 Tahun $2018 \quad$ Tentang Pendaftaran Tanah Sistematis Lengkap.

Peraturan Menteri Agraria Dan Tata Ruang/Kepala Badan Pertanahan Nasional Nomor 18 Tahun 2019 tentang Tata Cara Penatausahaan Tanah Ulayat Kesatuan Masyarakat Hukum Adat. 